2016

\title{
Empirical Study Redux on Choice of Law and Forum in M\&A: The Data and its Limits
}

Kyle Chen

Harold S. Haller

Juliet P. Kostritsky

CaseWestern University School of Law, juliet.kostritsky@case.edu

Wojbor A. Woyczynski

Follow this and additional works at: https://scholarlycommons.law.case.edu/faculty_publications Part of the Civil Procedure Commons

\section{Repository Citation}

Chen, Kyle; Haller, Harold S.; Kostritsky, Juliet P.; and Woyczynski, Wojbor A., "Empirical Study Redux on Choice of Law and Forum in M\&A: The Data and its Limits" (2016). Faculty Publications. 1639.

https://scholarlycommons.law.case.edu/faculty_publications/1639 


\title{
Empirical Study Redux on Choice of Law and Forum in M\&A: The Data and its Limits
}

\author{
Kyle Chen, Harold S. Haller, \\ Juliet P. Kostritsky, and \\ Wojbor A. Woyczynski
}

Case Research Paper Series in Legal Studies

Working Paper 2016-13

April 2016 
EMPIRICAL STUDY REDUX ON CHOICE OF LAW AND FORUM IN M\&A: THE DATA AND ITS LIMITS

\author{
Kyle Chen ${ }^{1}$, Harold S. Haller ${ }^{2}$, Juliet P. Kostritsky ${ }^{3}$, \\ Wojbor A. Woyczynski ${ }^{4}$
}

I. INTRODUCTION

II. DATA FOR ANALYSIS

III. DATA ANALYSES

A. Contingency Table Analyses-State of Incorporation Versus State for Choice of Law

B. Logistic Regression Analyses

i) Brief Introduction to Logistic Regression.

ii) Logistic Regression Model for Choice of Law Delaware

iii) Logistic Regression Model for Choice of Law New York

iv) Logistic Regression Model for Choice of Forum Delaware.

v) Logistic Regression Model for Choice of Forum New York

vi) Logistic Regression Model for Acquirer Incorporates in Delaware

IV. EMPIRICAL RESEARCH: THE IMPLICATIONS FOR SCHOLARLY RESEARCH WITH DATA

A. Determining How Much Data Is Necessary to Draw Conclusions

B. Studying a Flight from Delaware: A Complex Subject for Analysis

C. Determining Whether Raw Numbers Can Illuminate Party Choice

V. CONCLUSION

\footnotetext{
${ }^{1}$ Attorney at Sughrue Mion, PLLC; Juris Doctor, Notre Dame Law School, Class of 2015.

${ }^{2}$ Director of the Case Statistical Consulting Center, Department of Mathematics, Applied Mathematics, and Statistics, Case Western Reserve University.

${ }^{3}$ Everett D. and Eugenia S. McCurdy Professor of Contract Law at Case Western Reserve University School of Law.

${ }^{4}$ Professor of Mathematics, Applied Mathematics, and Statistics; and, Director, Center for Stochastic and Chaotic Processes in Sciences and Technology Case Western Reserve University.

We wish to thank Professors Charles Korsmo, Ronald J. Coffey and David Porter for their helpful comments. Kathleen Harvey, George Skupski and Aurelia Tunru provided superb research assistance.
} 


\begin{abstract}
The legal community has long recognized that business corporations heavily favor Delaware as the state of incorporation. However, a recent study of merger agreements from 2002 by Eisenberg and Miller suggested that, despite Delaware's prominence as the place of incorporation, companies "flee" from Delaware with respect to both choice of law and forum, and instead prefer New York. We set out to study data from 343 merger and acquisitions contracted on between January 1, 2011 and June 30, 2011 in an attempt to verify this conjecture. Our study is important for two reasons. First, the 2011 data set shows that the Eisenberg and Miller conjecture is not supported in view of the new tools applied in our work. Specifically, we find that the state of incorporation has no effect on the choice of law for the state of New York, thus negating the earlier finding that Delaware corporations flee to New York law. The choice of forum being New York or some other forum is the major factor in our model, explaining about 50\% of the variation in the choice of law for the state of New York. Thus, Eisenberg and Miller may have identified a transient phenomenon. Second, the article contributes to the debate about whether raw data alone can contribute to an understanding of a phenomenon such as the choice of law. We argue that, without further context such as a survey of the lawyers drafting the merger agreements, the usefulness of purely quantitative data is limited.
\end{abstract}

\title{
I. INTRODUCTION
}

Parties to mergers and acquisitions often include choice of law and choice of forum provisions in their agreements. Choice of law provisions determine which state's law will govern in case of a contractual dispute. ${ }^{5}$ Choice of forum provisions ${ }^{6}$ determine which court will apply the law. Parties are reluctant to split choice of law and choice of forum, tending to prefer a court to apply its own state's laws. ${ }^{7}$ Delaware dominates parties' choice of law and choice of forum provisions. ${ }^{8}$ Delaware's prominence has prompted several scholars to study the reasons for and effects of choice of law and choice of forum decisions.

${ }^{5}$ Larry E. Ribstein, Choosing Law by Contract, 18 J. CORP. L. 245, 245 (1993).

${ }^{6}$ Such clauses choosing forum "are now routinely enforced." Geoffrey P. Miller \& Theodore Eisenberg, The Market for Contracts, 30 CARDOZO L. REV. 2073, 2078 (2009). "They can reduce dispute resolution costs, promote efficient contracting, and enhance functional specialization in the judiciary." Joseph A. Grundfest, The History and Evolution of Intra-Corporate Forum Selection Clauses: An Empirical Analysis, 37 DEL J. CORP. L. 333, 335 (2012) (covering the history of forum choice and its recognition by the Supreme Court but focusing more narrowly on instances in which the forum choice appears in the company charter).

${ }^{7}$ Theodore Eisenberg \& Geoffrey Miller Ex Ante Choices of Law and Forum: An Empirical Analysis of Corporate Merger Agreements, 59 VAND. L. REV. 1973 (2006).

${ }^{8}$ Id. at 1982. 
Professors Theodore Eisenberg and Geoffrey Miller claimed a flight from Delaware to New York choice of law" in merger agreements, suggesting that "once one accounts for Delaware as the place of incorporation, firms tend to flee Delaware as a choice of law and forum." ${ }^{10}$ Eisenberg and Miller based their flight finding on a study of merger agreements in 2002. ${ }^{11}$ Law and economists subsequently cited the flight to support the notion that companies preferred the formalism of New York and thus, by implication, were consciously avoiding the law of Delaware. ${ }^{12}$ To test the Eisenberg and Miller conjecture, we compiled a later data set from the SEC EDGAR database ${ }^{13}$ using a sixmonth period in 2011.

Our criticisms of the original Eisenberg and Miller paper fall into two basic categories; one is data driven and the other is based on the limits of empirical research.

First, our six months of 2011 merger data suggest that the conjectures of Eisenberg and Miller based on the 2002 merger data can no longer be supported in view of the new tools applied in our work. They conclude that "Delaware corporations tend to choose Delaware law less than other corporations choose the law of their state of incorporation" 14 and that indicates a flight away from Delaware law. We used a twofactor contingency table to test whether the 2011 merger history supports the Eisenberg and Miller claims. Based on this analysis, there is no presumption that the percentage of acquiring companies incorporated in Delaware that choose Delaware law is less than the percentage of mergers in states other than Delaware choosing the same non-Delaware state's law.

Specifically, our two way tables reveal that for 2011 the actual percentage of Delaware corporations that choose Delaware law, 65\%, is not significantly different from the percentage of incorporations in states other than Delaware that select the same state other than Delaware for their choice of law, 70\%, (P-value 34\%). Thus, the 2011 data shows that the Eisenberg and Miller conjecture based on the 2002 data can no longer be supported. Eisenberg and Miller reached a correct conclusion based on their data, but these results cannot be extrapolated into the future because of the transient nature of the data. They may have, therefore, identified a transient phenomenon. ${ }^{15}$

Second, to gain a deeper understanding, we used multivariate logistic regression in the analysis of the 2011 merger data. Eisenberg and Miller also used these more advanced methods in their analysis of the 2002 merger data, but they commented

\footnotetext{
${ }^{9}$ Parties are free to choose what law they want to govern their merger agreement. See Ribstein, supra note 5, at 247-48. In deciding whether to give effect to choice of law provisions in merger agreements, courts distinguish between corporate matters and peripheral ones. For corporate matters, even if the parties have chosen another state law, courts will apply the law of the state of incorporation to corporate matters under the "internal affairs doctrine." Id. at 266.

${ }^{10}$ Eisenberg \& Miller, supra note 7.

${ }^{11} \mathrm{Id}$.

${ }^{12}$ See Jody S. Kraus \& Robert E. Scott, Contract Design and the Structure of Contractual Intent, 84 N.Y.U. L. REV. 1023, 1061-62 (2009).

${ }^{13}$ These merger agreements are accessible to the public. See http://www.sec.gov/edgar.shtml.

${ }^{14}$ Eisenberg \& Miller, supra note 7, at 1973.

${ }^{15}$ See infra Part IV. It is unlikely that our results will agree with Eisenberg and Miller because, as stated in the paper, choices of states in which to incorporate and choices of state's law and forum for litigation is not a stable system with respect to time.
} 
"statistical theory has made only modest progress in solving complex systems of equations involving categorical data." $16 \mathrm{We}$ strongly disagree with this assertion. ${ }^{17}$ Both our bi-variate tables and those of Eisenberg and Miller have shown there are interdependencies between the variables associated with mergers: choice of law; choice of forum; locations of acquiring and acquired firms' places of business; locations of attorneys of acquiring and acquired firms' offices; state of incorporation; and whether the acquirer and acquired are public firms. These interdependencies make it more important to use multivariate methods to adjust the data for interdependencies in order to estimate the effects of each factor independent of the other factors. Without such adjustments, bivariate tables may indicate associations that are due to factors common to both variates rather than to the variates themselves. Eisenberg and Miller did not think it was possible to "fully model[] all or even most of the dependencies that exist in the models reported." 18 They stated that logistic regression is not as powerful as their bi-variate analyses. However, we are confident that by using multivariate methods we have estimated the effects of each factor independent of the other. Thus, we have greater confidence in the regression's ability to isolate each factor than Eisenberg and Miller did. ${ }^{19}$ They did not think their logistic regression analysis was as powerful as their bi-variate analysis. ${ }^{20}$

Our main conclusion is that the choice of law and choice of forum are highly dependent. The choice of forum in Delaware explains almost $58 \%$ of the variation in the choice of law in Delaware. But, considering all the factors from Table $1,{ }^{21}$ we found that if the acquirer incorporates in Delaware and chooses Delaware as the forum and the acquirer's corporate office is not New York, the choice of law will be Delaware.

In contrast to the Eisenberg and Miller study, our data set reveals that the state of incorporation has no effect on the choice of law being New York. But if the company is incorporated in Delaware, it is most likely to choose Delaware as the choice of law to govern the merger agreement. Thus, the state of incorporation clearly has an effect on the choice of law for Delaware but not New York. This conclusion is contrary to the

\footnotetext{
${ }^{16}$ Eisenberg \& Miller, supra note 7, at 1994.

${ }^{17}$ DAVID Hosmer \& StAnley Lemshow, ApPlied Logistic Regression, (John Wiley \& Sons, Inc. New York (2000)).

${ }^{18}$ Eisenberg \& Miller, supra note 7, at 1994.

${ }^{19}$ Eisenberg and Miller concluded "the simple descriptive story suggested by the bivariate tables throughout this article is reasonably consistent with the regression models we report." Id. at 1994. However, their use of multivariate logistic regression ignores the importance of eliminating variables in the analysis that are not statistically significant. See discussion of the principle of parsimony in Hosmer, et al, supra note 17, at 1. That may explain why Eisenberg and Miller were less confident in the ability of their logistic regression models to fully account for all of the factors. $I d$. at 1994. Without the removal of statistically insignificant variables, we cannot gain a full picture of the effects of each factor independent of the others. Because our study has eliminated factors that are not statistically significant, we are confident in the ability of our regression methods to isolate the effects of each factor independent of the other factors. Our regression method demonstrates: 1) what factors explain why mergers choose Delaware law; 2) the non-effect of the state of incorporation on the choice of law in New York, and; 3) the fact that a major factor explaining the choice of law in New York is the choice of forum.

${ }^{20}$ Eisenberg \& Miller supra note 7, at 1994.

${ }^{21}$ See infra Table 1.
} 
conclusion reached in the Eisenberg and Miller study that, if a company is incorporated in Delaware, the company has a tendency to choose New York law.

That non-effect of incorporation on the choice of law in New York seems to negate the Eisenberg and Miller conjecture connecting Delaware incorporation to a choice of law in New York. Our study revealed a different factor that accounts for a choice of law being New York. The highest probability that the choice of law is New York occurs when the choice of forum is New York, the acquired entity is private, and the attorney does business in New York. ${ }^{22}$ Ultimately, our analysis of the 2011 data set of mergers demonstrates that Eisenberg and Miller's conclusion that companies flee Delaware can no longer be supported in view of the new tools applied in our work.

Our second criticism of the Eisenberg and Miller study is broader in nature and not directed at the data. ${ }^{23}$ We argue that it is difficult to draw meaningful conclusions from raw numbers without additional context or consideration of the reasons for a phenomenon such as the choice of law in merger agreements. For several reasons explored in this paper, we argue that without that additional information or context, the numbers alone may not be able to tell us very much.

First, building a theory that companies are fleeing Delaware law based on the excess of incorporations over choice of law is problematic. ${ }^{24}$ It might be entirely unsurprising that there is a net outflow from Delaware, but it is be strange to jump immediately to the conclusion that there is an aversion to Delaware law.

Second, an outflow from Delaware is possible in the first place because there is such a tremendous inflow into Delaware due to the perceived benefits of the legal system. Conversely, there can hardly help but be an inflow to New York given the dearth of New York incorporations.

Third, it is unclear how much the raw numbers on choice of law and/or forum tell us about the desirability of either jurisdiction's law. It is difficult to draw any meaningful conclusions without knowing why or if there was a flight. To prove a flight, you need to demonstrate that the decision to leave a jurisdiction was knowing, volitional, and deliberate with respect to the content of the law of a jurisdiction. To reach meaningful conclusions about a choice, it would be important to interview lawyers regarding the thinking underlying the choice of law in a merger agreement. That data is now available for the same set of merger agreements we studied to assess whether the Eisenberg and Miller conjectures of a flight to New York held true in 2011. ${ }^{25}$

One surprising result of using logistic regressions for choice of law in New York is that it reveals a Delaware state of incorporation has no effect on the choice of law for

\footnotetext{
22 See infra Table 6.

${ }^{23}$ Empiricists build models of reality using these large data sets and regression. See Michael Heise, The Past, Present, and Future of Empirical Legal Scholarship: Judicial Decision Making and the New Empiricism, 2002 U. ILL. L. REV. 819 (2002) (positing that statistical methods are integral to empirical studies).

${ }^{24}$ Eisenberg and Miller built the idea of flight on the fact that the number of mergers incorporated in Delaware (189) exceeded the choice of law for Delaware (132). Similarly, "115 contracts that designated a forum had Delaware corporate acquirers" and stipulated a Delaware forum. Eisenberg \& Miller, supra note 7, at 1982.

${ }^{25}$ See Juliet P. Kostritsky, Context Matters-What Lawyers Say About Choice of Law Decisions in Merger Agreements, 13 DePaul Bus. \& CoM. L.J. 211, 218 (2015).
} 
New York. Rather, the analysis revealed that the major factor, accounting for $50 \%$ of the variation, for the choice of law in New York is the choice of forum. ${ }^{26}$ The Choice of Forum Delaware explains $58 \%$ of the variation in the Choice of Law Delaware. ${ }^{27}$ Of the 188 DE incorporations, 113, or 60 percent, had choice of forum in Delaware. There were 55 incorporations in states and countries other than Delaware and of these 33, or 60 percent, had choice of forum in the same state or country. The frequency of a merger choosing the state for their forum to be the same as the state of incorporation is the same, whether the state is Delaware or another state or country. This article will suggest that forum may be such a significant factor in the choice of law because lawyers are reluctant to split the forum and the substantive law choice. Lawyers prefer to have one court decide the case and apply that forum's law to the dispute. ${ }^{28}$ They are concerned that, if one forum decides the case but applies the substantive law of another jurisdiction, the forum court may misapply the law of the other jurisdiction..$^{29}$

Part II will present the data for analysis. Part III will analyze the data using bivariate and multivariate logistic regression and state our main conclusions drawn from the analysis. Part IV will explore the limits of using raw data for examining a phenomenon such as the parties' choice of law without further contextual evidence about the choice made by the drafting parties. It will suggest avenues for further research. Part V summarizes our conclusions.

\section{DATA FOR ANALYSIS}

Eisenberg and Miller reported on 412 merger acquisition contracts contained in SEC Form 8-K filings ${ }^{30}$ for a seven month period from January 2002 to July $2002 .{ }^{31}$ With the exception of seven mergers for which both Delaware and New York were listed as the choice of law, these data were a complete count of merger activities reported in the SEC EDGAR database. On an annual basis, there were about 700 mergers per year in 2002.

In our current research, data from a total of 343 corporate mergers were gathered using SEC Form 8-K filings in the six month period from January 1, 2011 through June $30,2011 .{ }^{32}$ Prorating this figure suggests there were about 690 mergers in 2011, which compares favorably to the number of mergers in 2002 studied by Eisenberg and Miller. ${ }^{33}$ The variables associated with these mergers are listed in Table 1, including the frequency

${ }^{26}$ See infra Part III(B)(iii) (parameter estimates).

${ }^{27}$ See infra Part III(B)(ii) (parameter estimates).

${ }^{28}$ See Kostritsky, supra note 25, at 224 n.46 (citing to lawyer interview in which lawyer indicated she never bifurcates forum and governing law).

${ }^{29} I d$. at 224.

30 "In addition to filing annual reports on Form 10-K and quarterly reports on Form 10-Q, public companies must report certain material corporate events on a more current basis. Form $8-\mathrm{K}$ is the "current report" companies must file with the SEC to announce major events that shareholders should know about." These would include merger agreements. http://perma.cc/SQG9-2D8X.

${ }^{31}$ Eisenberg \& Miller, supra note 7, at 1985.

${ }^{32}$ See supra note 30.

${ }^{33}$ Eisenberg \& Miller, supra note 7. 
associated with each. It should be noted that these are all nominal variables for which the response was "yes" or "no" based on the SEC Form 8-K filings.

Table 1 - Variables Available for Analysis

\begin{tabular}{|l|l|}
\hline Variable Name & n \\
\hline Acquirer Incorporated in DE & 188 \\
\hline Acquirer Incorporated in NY & 2 \\
\hline Acquirer Incorporated in CA & 4 \\
\hline Acquirer Incorporated in Other State than DE, NY, CA & 147 \\
\hline Acquirer Corporate Headquarters in NY & 29 \\
\hline Acquirer Corporate Headquarters in CA & 67 \\
\hline Acquirer Corporate Headquarters in DE & 1 \\
\hline $\begin{array}{l}\text { Acquirer Corporate Headquarters in Other State than DE, } \\
\text { NY, CA }\end{array}$ & 246 \\
\hline Acquirer Attorney Does Business in CA & 61 \\
\hline Acquirer Attorney Does Business in NY & 91 \\
\hline $\begin{array}{l}\text { Acquirer Attorney Does Business in Other State than NY } \\
\text { or CA }\end{array}$ & 191 \\
\hline Acquired Incorporated in DE & 11 \\
\hline Acquired Attorney Does Business in CA & 58 \\
\hline Acquired Attorney Does Business in NY & 69 \\
\hline Choice of Law NY & 47 \\
\hline Choice of Law DE & 162 \\
\hline Choice of Law CA & 13 \\
\hline Choice of Forum NY & 51 \\
\hline Choice of Forum DE & 132 \\
\hline Choice of Forum CA & 14 \\
\hline Acquirer Private & 88 \\
\hline Acquired Private & 188 \\
\hline & \\
\hline
\end{tabular}

Cain and Davidoff ${ }^{34}$ studied 1,020 mergers for a five year period of time, 2004 through 2008, but chose to ignore acquisitions of private targets. ${ }^{35}$ With this more restrictive criterion for including mergers, their data only represent about 200 mergers per year during the 2004 to 2008 period. But this was a period of robust economic activity as measured by GDP, which increased until leveling off in 2008 as shown in Figure 1. Thus, given that Cain and Davidoff studied a smaller subset of mergers over a longer period of time, it is difficult to compare the results of Cain and Davidoff ${ }^{36}$ with those of Eisenberg and Miller ${ }^{37}$ and our current 2011 study.

${ }^{34}$ Matthew D. Cain \& Steven M. Davidoff, Delaware's Competitive Reach, 9 J. EMPIR. L. STUD. 92 (2012).

${ }^{35} I d$. at 94 .

${ }^{36} \mathrm{Id}$.

${ }^{37}$ Eisenberg \& Miller, supra note 7. 
Figure 1

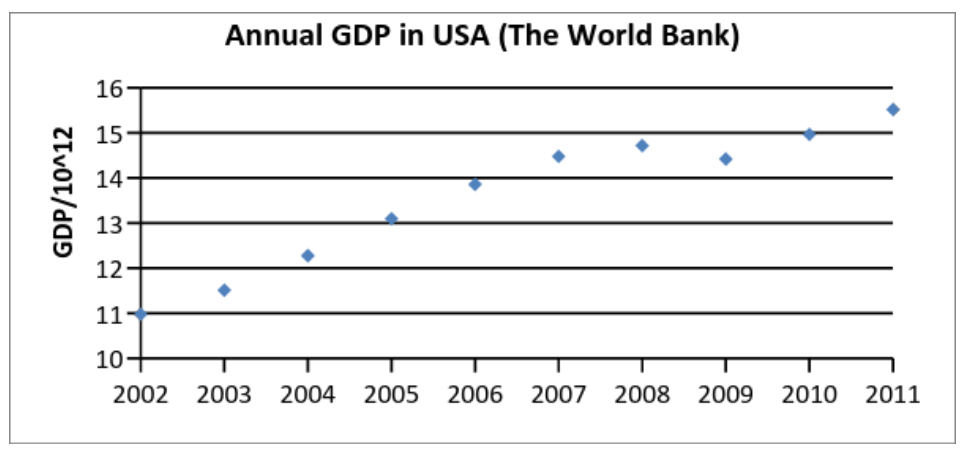

It should be pointed out that the mergers studied in 2002 and 2011 were not a convenience or a random sample, but rather a complete count based on the SEC EDGAR database. Thus, one of the major objections raised by Cain and Davidoff ${ }^{38}$ to including mergers with acquired (target) private companies is moot because there can be no skewing due to the complete sampling based on the 2002 and 2011 data. Rather, the factor "Acquired Private," which was included as a potential variable in analyses by Eisenberg and Miller ${ }^{39}$ as well as our study, was found to introduce a statistically significant bias in 2011 time periods for some of the responses analyzed. Finally, any comparison of results from 2002 with 2011 must be viewed along with the potential impact of both political and economic factors, which neither the Eisenberg and Miller nor our present study can include. For example, the 2008 recession and sluggish recovery that lasted for at least six years and the passage of the Affordable Care Act are two interventions that could have profound impact on acquisition contracts. From Figure 1, the sluggish recovery of the US economy following the 2008 recession is indicated by change in the slope of the GDP curve: 0.72 from 2002 to 2007 and 0.55 from 2009 to 2011.

\section{DATA ANALYSES}

Before reviewing the analyses of the 2011 merger data, consider the summary data in Table $1 .{ }^{40}$ First, among the 343 mergers, only two were acquirer incorporations in New York and four in California. Thus, any analyses of, or conclusions related to, acquirer state of incorporation must be restricted to Delaware versus all other states. Second, only one out of 343 acquirer corporate headquarters was located in Delaware. So the variable "Acquirer Corporate Headquarters" was restricted to New York, California, and states other than Delaware. With these caveats, the analyses of the nominal merger

\footnotetext{
${ }^{38} I d$.

${ }^{39} I d$. at 1996.

${ }^{40}$ See infra Table 1.
} 
data consisted of two factor or two-way contingency table analyses and multivariate logistic regression models for specific responses.

\section{A. Contingency Table Analyses - State of Incorporation Versus State for Choice of Law}

Eisenberg and Miller claim, "Delaware corporations tend to choose Delaware law less than other corporations choose the law of their states of incorporation." 41 With this hypothesis in mind, consider the following contingency table that was formed using the 2011 merger data. Clearly, both New York and California had too few incidences of the acquirer's choice of state in which to incorporate. Thus further analysis of this table in its present granular form is meaningless from a statistical point of view because $20 \%$ of the cells have expected values less than 5 .

Table 1

\begin{tabular}{|l|c|c|c|c|c|}
\hline $\begin{array}{l}\text { Count } \\
\text { Total \% } \\
\text { Col \% } \\
\text { Row \% }\end{array}$ & $\begin{array}{l}\text { Acquirer } \\
\text { Inc. in DE }\end{array}$ & $\begin{array}{l}\text { Acquirer Inc. } \\
\text { in NY }\end{array}$ & $\begin{array}{l}\text { Acquirer Inc. } \\
\text { in CA }\end{array}$ & $\begin{array}{l}\text { Acquirer Inc. in } \\
\text { Other State }\end{array}$ & \\
\hline & 122 & 0 & 0 & 40 & 162 \\
Choice of Law & 35.57 & 0.00 & 0.00 & 11.66 & $47.23 \%$ \\
DE & 64.89 & 0.00 & 0.00 & 26.85 & \\
& 75.31 & 0.00 & 0.00 & 24.69 & \\
\hline & 25 & 1 & 0 & 16 & 42 \\
Choice of Law & 7.29 & 0.29 & 0.00 & 4.66 & $12.24 \%$ \\
NY & 13.30 & 50.00 & 0.00 & 10.74 & \\
& 59.52 & 2.38 & 0.00 & 38.10 & \\
\hline & 4 & 1 & 3 & 4 & 12 \\
Choice of Law & 1.17 & 0.29 & 0.87 & 1.17 & $3.50 \%$ \\
CA & 2.13 & 50.00 & 75.00 & 2.68 & \\
& 33.33 & 8.33 & 25.00 & 33.33 & \\
\hline & 37 & 0 & 1 & 89 & 127 \\
Choice of Law & 10.79 & 0.00 & 0.29 & 25.95 & $37.03 \%$ \\
Other State & 19.68 & 0.00 & 25.00 & 59.73 & \\
& 29.13 & 0.00 & 0.79 & 70.08 & \\
\hline & 188 & 2 & 4 & 149 & 343 \\
& $54.81 \%$ & $0.58 \%$ & $1.17 \%$ & $43.44 \%$ & \\
\hline
\end{tabular}

Consolidating the New York and California states of incorporation categories with the "Other" state of incorporation category results in the contingency table shown in Table 2. The following likelihood ratio test reveals that the occupancy numbers shown in the first row of each cell in Table 2 are not statistically independent (P-value $<0.01 \%)$.

${ }^{41}$ See Eisenberg \& Miller, supra note 7, at 1973. 
Tests

\begin{tabular}{|c|c|c|c|}
\hline $\mathbf{N}$ & DF & -Log Like & RSquare (U) \\
\hline 343 & 3 & 33.006002 & 0.1398 \\
\hline $\begin{array}{l}\text { Test } \\
\text { Likeli }\end{array}$ & & ChiSquare & Prob>ChiSq \\
\hline
\end{tabular}

This Chi-Square test compares the percentages shown in the second line of each cell of the 4-by-2 table assuming independence. The fact that the Chi-Square statistic is large $(\mathrm{P}<0.01 \%)$ is another way of saying that acquirer's state of incorporation and choice of law are not statistically independent.

Table 2

\begin{tabular}{|c|c|c|c|}
\hline $\begin{array}{l}\text { Count } \\
\text { Total \% } \\
\text { Col \% } \\
\text { Row \% }\end{array}$ & $\begin{array}{l}\text { Acquirer } \\
\text { Inc. in DE }\end{array}$ & $\begin{array}{l}\text { Acquirer Inc. } \\
\text { in Other State } \\
\text { than DE }\end{array}$ & \\
\hline $\begin{array}{l}\text { Choice of } \\
\text { Law DE }\end{array}$ & $\begin{array}{c}122 \\
35.57 \\
64.89 \\
75.31\end{array}$ & $\begin{array}{c}40 \\
11.66 \\
25.81 \\
24.69\end{array}$ & $\begin{array}{c}162 \\
47.23 \%\end{array}$ \\
\hline $\begin{array}{l}\text { Choice of } \\
\text { Law NY }\end{array}$ & $\begin{array}{c}25 \\
7.29 \\
13.30 \\
59.52\end{array}$ & $\begin{array}{c}17 \\
4.96 \\
10.97 \\
40.48\end{array}$ & $\begin{array}{c}42 \\
12.24 \%\end{array}$ \\
\hline $\begin{array}{c}\text { Choice of } \\
\text { Law CA }\end{array}$ & $\begin{array}{c}4 \\
1.17 \\
2.13 \\
33.33\end{array}$ & $\begin{array}{c}8 \\
2.33 \\
5.16 \\
66.67\end{array}$ & $\begin{array}{c}12 \\
3.50 \%\end{array}$ \\
\hline $\begin{array}{c}\text { Choice of } \\
\text { Law Other } \\
\text { State }\end{array}$ & $\begin{array}{c}37 \\
10.79 \\
19.68 \\
29.13\end{array}$ & $\begin{array}{c}90 \\
26.24 \\
58.06 \\
70.87\end{array}$ & $\begin{array}{c}127 \\
37.03 \%\end{array}$ \\
\hline & $\begin{array}{c}188 \\
54.81 \%\end{array}$ & $\begin{array}{c}155 \\
45.19 \%\end{array}$ & 343 \\
\hline
\end{tabular}

But consider the results for Choice of Law NY in Table 2. In the first six months of 2011 there were 42 mergers in which the choice of law was New York. Of these mergers, 25 or $59.52 \%$ were incorporated in Delaware and 17 or $40.48 \%$ were incorporated in states other than Delaware. Testing the alternative hypothesis "flight from Delaware" incorporation for choice of law New York versus the null hypothesis of "no flight from Delaware" incorporation for Choice of Law New York reveals there is 
insufficient information to reject this null hypothesis in favor of the alternative (P-value $21.7 \%)$. This result is contrary to the claims by Eisenberg and Miller. ${ }^{42}$

Eisenberg and Miller further claim that — based on 2002 merger data - "Delaware corporations tend to choose Delaware law less than other corporations choose the law of their state of incorporation." ${ }^{43}$ To test this hypothesis, consider the cases from Table 1 where the state of incorporation and the state for choice of law are the same. There were 122 mergers incorporated in Delaware that chose Delaware law, but 66 that did not choose Delaware law. There was one New York incorporation out of two that chose New York as the choice of law, but the other choice of law was a state other than Delaware. There were three out of four mergers incorporated in California that chose California as the choice of law, but the other merger did not choose Delaware as the choice of law. Finally there were 89 mergers incorporated in other states that chose other states for the choice of law. We will assume that these choices of law were the same as the states of incorporation for this analysis. Then there were 40 mergers incorporated in other states that did not choose Delaware as the choice of law. These are summarized as a two-by-two contingency table in Table 3.

The following test statistics indicate that acquirer's choice of state of incorporation is not independent of the state for choice of law, which the earlier more granular test revealed from the 4-by-2 table (P-value $<0.01 \%)$.

\section{Tests}

\begin{tabular}{|c|c|c|c|}
\hline \multirow{2}{*}{$\begin{array}{c}\mathbf{N} \\
321\end{array}$} & DF & -Log Like & RSquare (U) \\
\hline & 1 & 19.313414 & 0.0887 \\
\hline \multicolumn{2}{|c|}{ Test } & ChiSquare & Prob $>$ ChiSq \\
\hline & & 38.627 & $<.0001^{*}$ \\
\hline & & 37.776 & $<.0001^{*}$ \\
\hline
\end{tabular}

Table 3

\begin{tabular}{|l|c|c|c|}
\hline $\begin{array}{l}\text { Count } \\
\text { Total \% } \\
\text { Col \% } \\
\text { Row \% }\end{array}$ & $\begin{array}{l}\text { State of Inc. } \\
\text { Other than } \\
\text { DE }\end{array}$ & $\begin{array}{l}\text { State of Inc. } \\
\text { DE }\end{array}$ & \\
\hline Choice of & 93 & 66 & 159 \\
Law Other & 28.97 & 20.56 & $49.53 \%$ \\
State & 69.92 & 35.11 & \\
& 58.49 & 41.51 & \\
\hline Choice of & 40 & 122 & 162 \\
Law DE & 12.46 & 38.01 & $50.47 \%$ \\
& 30.08 & 64.89 & \\
& 24.69 & 75.31 & \\
\hline & 133 & 188 & 321 \\
& $41.43 \%$ & $58.57 \%$ & \\
\hline
\end{tabular}

\footnotetext{
${ }^{42}$ Eisenberg \& Miller, supra note 7.

${ }^{43} I d$. at 1973.
} 
In Table 3, 122 of the 188 mergers that incorporated in Delaware chose Delaware law while 93 of the 133 mergers that incorporated in states other than Delaware chose another state's law than Delaware. Note that this does not mean in these 93 mergers that the other state of incorporation and the other state of law were the same state, except for these four: one from New York and three from California. But we are assuming the best case scenario for these 93 cases: namely that the state of incorporation and the choice of law are the same state other than Delaware. The Eisenberg and Miller conjecture based on their 2002 data can be tested from the data in Table 3. Here, the null hypothesis is that the percentage of incorporations and choice of law in Delaware and the percentage of incorporations and choice of law in states other than Delaware are the same. The alternative, according to Eisenberg and Miller, is that there is flight from Delaware law. There is not enough information in 2011 merger data to accept the alternative hypothesis posed by Eisenberg and Miller (P-value 34\%). In the first six months of 2011, the actual percentage of incorporations in Delaware that choose Delaware law, 65\%, is not significantly different from the percentage of incorporations in other states than Delaware that select the same other state than Delaware for their choice of law, 70\%, with the conservative assumption ${ }^{44}$ about the other states of incorporation and choice of law. Thus, the Eisenberg and Miller conjecture based on 2002 merger history is not true based on 2011 merger history.

\section{B. Logistic Regression Analyses}

While two factor contingency tables and their analyses above revealed that the conjectures of Eisenberg and Miller based on seven months of 2002 merger data can no longer be supported in view of the new tools applied in our work based on six months of 2011 merger data, what do these more recent data reveal about choices of law and forum relative to mergers in 2011 and Delaware as a state of incorporation? To address questions similar to these, Cain and Davidoff used more advanced and powerful analytical methods to analyze the merger data from 2004 to 2008, namely multivariate logistic regression. ${ }^{45}$ Thus, the remainder of our analyses will utilize this methodology to further understand merger trends based on mergers in the first half of 2011.

\footnotetext{
${ }^{44}$ The two-way table was for choice of law and state of incorporation. For both choice of law and state of incorporation, the two choices were Delaware and Other. The conservative assumption was that Other referred to the same state. For example, if Other state of choice was Ohio, the other state of incorporation was also Ohio. But in reality, the Other state of law might be Ohio and the Other state of incorporation might be Kentucky.

${ }^{45}$ Cain \& Davidoff, supra note 34.
} 


\section{i) Brief Introduction to Logistic Regression}

All of the factors, $Y$, listed in Table 1 are nominal in the sense that the variables are either true or false. In logistic regression analysis, one of the variables in Table 1, a random variable $Y$, is defined as $Y=1$, and $Y=0$ if the response is true or false, respectively. Supposing the probability that $Y=1$ is $p$, which is unknown, and the probability that $Y=0$ is $(1-p)$, we consider the following model:

$$
Y=f(\underline{x})+\varepsilon
$$

Here, $f(\underline{x})$ is an unknown function of a subset of variables other than $Y$ listed in Table 1 , while $\varepsilon$ is a random variable with mean zero and some unknown but constant standard deviation, $\sigma$. Taking the expectation of equation (1), we get, $E(Y)=f(\underline{x})$. But from the definition of $Y$, we get expected value of $Y, E(Y)=1 * p+0 *(1-p)=p$. Thus the unknown function, $f(\underline{x})$, is the unknown probability of a true answer, $p$, for response $Y$. Using the definition of variance, the variance of the left and right hand side of equation (1) is: Variance of $Y=V(Y)=(1-p)^{2} p+(0-p)^{2}(1-p)=p(1-p)$, and $V(Y)=V(\varepsilon)=\sigma^{2}$. Combining the two results indicates that the variance assumption of linear regressionthat the variance is a constant - is violated, which means the data must be transformed to stabilize the variance. The following logistic transformation, which is the natural logarithm of the odds ratio, is one way to stabilize the variance of Y. This transformation is defined as follows.

$$
T(Y)=\ln \left[\frac{Y}{1-Y}\right]=\ln \left[\frac{f(\underline{x})}{1-f(\underline{x})}\right]
$$

The maximum likelihood estimators of the parameters in the model $f(\underline{x})$ can be computed from the transformed variable $T(Y)$ in equation (2) with the software program JMP8®. Using this software, the probability generated is the probability of "Not 0 ", which is $1-f(\underline{x})$.

With this brief introduction to logistic regression we will now address the questions posed above relative to choice of law, choice of forum, and state of incorporation using this more advanced and powerful statistical method to gain a deeper understanding of merger decisions.

\section{ii) Logistic Regression Model for Choice of Law Delaware}

The following contingency table, Table 4, reveals that the choice of law and forum are highly dependent. In particular note the figures in the third row of each cell where Choice of Law and Forum are in the same state range from $66.7 \%$ to $94.5 \%$. Though the Chi-Square value associated with Table 4 is a statistically significant value (Chi-Square 445.1 has P-value $<0.01 \%$ ) indicating that choice of law and forum are not independent, $20 \%$ of cells have an expected count of less than 5, which makes the ChiSquare value suspect. 
Tests

\begin{tabular}{|c|c|c|c|}
\hline $\mathbf{N}$ & DF & -LogLike & RSquare (U) \\
\hline 343 & 9 & 222.54820 & 0.5917 \\
\hline & Ratio & $\begin{array}{l}\text { ChiSquare } \\
445.096\end{array}$ & $\begin{array}{l}\text { Prob }>\text { ChiSq } \\
<.0001^{*}\end{array}$ \\
\hline
\end{tabular}

Table 4

\begin{tabular}{|l|c|c|c|c|c|}
\hline $\begin{array}{l}\text { Count } \\
\text { Total \% } \\
\text { Col \% }\end{array}$ & $\begin{array}{l}\text { Choice of } \\
\text { Law DE } \\
\text { Row \% }\end{array}$ & $\begin{array}{l}\text { Choice of } \\
\text { Law NY }\end{array}$ & $\begin{array}{l}\text { Choice of } \\
\text { Law CA }\end{array}$ & $\begin{array}{l}\text { Choice of } \\
\text { Law Other } \\
\text { States }\end{array}$ & \\
\hline Choice of & 130 & 1 & 0 & 1 & 132 \\
Forum DE & 37.90 & 0.29 & 0.00 & 0.29 & 38.48 \\
& 80.25 & 2.38 & 0.00 & 0.79 & \\
& 98.48 & 0.76 & 0.00 & 0.76 & \\
\hline Choice of & 5 & 37 & 0 & 3 & 45 \\
Forum & 1.46 & 10.79 & 0.00 & 0.87 & 13.12 \\
NY & 3.09 & 88.10 & 0.00 & 2.36 & \\
& 11.11 & 82.22 & 0.00 & 6.67 & \\
\hline Choice of & 3 & 0 & 8 & 3 & 14 \\
Forum & 0.87 & 0.00 & 2.33 & 0.87 & 4.08 \\
CA & 1.85 & 0.00 & 66.67 & 2.36 & \\
& 21.43 & 0.00 & 57.14 & 21.43 & \\
\hline Choice of & 24 & 4 & 4 & 120 & 152 \\
Forum & 7.00 & 1.17 & 1.17 & 34.99 & 44.31 \\
Other & 14.81 & 9.52 & 33.33 & 94.49 & \\
States & 15.79 & 2.63 & 2.63 & 78.95 & \\
\hline & 162 & 42 & 12 & 127 & 343 \\
& 47.23 & 12.24 & 3.50 & 37.03 & \\
\hline
\end{tabular}

As an alternative to the two-way contingency table approach for analyzing nominal data, consider the following logistic regression model for Choice of Law Delaware that contains three factors from the list of variables in Table 1.

\section{Parameter Estimates}

\section{Term}

Intercept

Choice of Forum New York?

Choice of Forum Delaware?

Choice of Forum California?

$\begin{array}{llll}\text { Estimate } & \text { Std Error } & \text { ChiSquare } & \begin{array}{l}\text { Prob>ChiSq } \\ <.0001^{*}\end{array} \\ -1.63323632 & 0.2186394 & 55.80 & 0.2348 \\ -0.64956051 & 0.5467398 & 1.41 & <.0001^{*} \\ +5.847847 & 0.7417692 & 62.15 & 0.6269 \\ +0.3339533 & 0.6870557 & 0.24 & \end{array}$

The only factor, $x$, from Table 1 in this model that is statistically significant is the Choice of Forum Delaware. Deleting both the Choice of Forum California and New York, 
the following new model is generated. From the model below, it follows that the Choice of Forum Delaware and Choice of Law Delaware are correlated.

$\begin{array}{ll}\text { RSquare (U) } & 0.5778 \\ \text { Observations (or Sum Wgts) } & 343\end{array}$

\section{Parameter Estimates}

Term

Intercept

Choice of Forum Delaware?

$\begin{array}{llll}\text { Estimate } & \text { Std Error } & \text { ChiSquare } & \begin{array}{l}\text { Prob>ChiSq } \\ -1.7216499\end{array} \\ 0.1919286 & 80.47 & <.0001^{*} \\ +5.8960261 & 0.7379183 & 63.84 & <.0001^{*}\end{array}$

Are there other factors from Table 1 that might help explain why mergers choose Delaware law? From the last print out, the Choice of Forum Delaware explains almost $58 \%(100 * \mathrm{RS}$ quare $(\mathrm{U}))$ of the variation in Choice of Law Delaware. We next considered other potentially important factors such as: the state of incorporation; the state where attorneys do business; whether the acquirer or acquired was a private entity; and what type of financial arrangements were used for the merger. Examining the response, Choice of Law Delaware, the use of logistic regression provides a multivariate analysis of all factors that could potentially impact this decision to choose Delaware law, not just the choice for state of forum. The resulting logistic regression model for Choice of Law Delaware is as follows.

\section{Parameter Estimates}

Term

Intercept

Choice of Forum Delaware?

Acquirer Inc. in Delaware?

Acquirer Corp. Office in New

York?

\begin{tabular}{|c|c|c|c|}
\hline Estimate & Std Error & ChiSquare & Prob $>$ ChiSq \\
\hline-2.75801238 & 0.3766659 & 53.61 & $<.0001^{*}$ \\
\hline+6.1931183 & 0.8084047 & 58.69 & $<.0001 *$ \\
\hline+1.9346607 & 0.44219 & 19.14 & $<.0001^{*}$ \\
\hline-2.05072381 & 1.067887 & 3.69 & 0.0548 \\
\hline
\end{tabular}

By transforming this model, Table 5 summarizes all combinations of probabilities, $f(\underline{x})$, obtained for the Choice of Law Delaware logistic regression model. 
Table 5

\begin{tabular}{|l|l|l|l|}
\hline $\begin{array}{l}\text { Probability } \\
\text { that Choice } \\
\text { of Law DE }\end{array}$ & $\begin{array}{l}\text { Acquirer } \\
\text { Inc. in } \\
\text { DE? }\end{array}$ & $\begin{array}{l}\text { Acquirer } \\
\text { Corp. } \\
\text { Office in } \\
\text { NY? }\end{array}$ & $\begin{array}{l}\text { Choice } \\
\text { of } \\
\text { Forum } \\
\text { DE? }\end{array}$ \\
\hline 0.98 & Yes & Yes & Yes \\
\hline 1.00 & Yes & No & Yes \\
\hline 0.05 & No & Yes & Yes \\
\hline 0.31 & No & No & Yes \\
\hline 0.89 & Yes & Yes & No \\
\hline 0.98 & Yes & No & No \\
\hline 0.01 & No & Yes & No \\
\hline 0.06 & No & No & No \\
\hline
\end{tabular}

From Table 5, it follows that the odds of the choice of law being Delaware following a merger are highest when the acquirer incorporates in Delaware (an average of 96\%). However, if the acquirer also chooses Delaware as the forum for litigation and the acquirer's corporate office is not in the state of New York, the probabilities are very high that the choice of law will be Delaware $(100 \%)$. Notice that if the acquirer does not incorporate in Delaware, the odds are less than about 30\% that the choice of law will be Delaware independent of state of the acquirer's corporate office or the choice of forum. Suppose we have two mergers in which the acquirers have the same corporate offices and chose the same forum. If one merger incorporates in Delaware and the other one does not, the odds are greater than 89 percent that the one that incorporated in Delaware will choose Delaware law. And the odds are less than 30 percent that the one that did not incorporate in Delaware will choose Delaware law.

\section{iii) Logistic Regression Model for Choice of Law New York}

In a similar manner, a model can be developed using logistic regression for Choice of Law New York, which helps to examine the "flight to New York" issue in more detail. The following logistic regression model was developed as the model for Choice of Law New York. Only statistically significant factors, $x$, from Table 1 are included in this model.

\section{Parameter Estimates}

Term

Intercept

Choice of Forum New York?

Acquirer Attorney bus. NY?

Target Private?

$\begin{array}{ll}\text { Estimate } & \text { Std Error } \\ -5.59266164 & 0.8357296 \\ +5.581297 & 0.6301622 \\ +1.4247077 & 0.662829 \\ +1.6529041 & 0.696324\end{array}$

ChiSquare
44.78
78.45
4.62
5.63

Prob $>$ ChiSq

$<.0001^{*}$

$<.0001^{*}$

$0.0316^{*}$

$0.0176^{*}$ 
This logistic model reveals other factors impacting the choice of law for the state of New York. But as the two-way contingency Tables 2 and 3 showed earlier, the model above indicates that the state of incorporation has no effect on the choice of law for the state of New York, which again negates the Eisenberg and Miller conjecture of "flight to New York".

Table 6 reveals the probabilities associated with various combinations of choice of law for New York, whether or not the attorney does business in the state of New York, and whether or not the acquired entity was private. The highest probability that the choice of law is the state of New York occurs when the choice of forum is New York, the attorney does business in the state of New York, and the acquired entity is private rather than public. The choice of forum being either New York or some other state is the major factor in this model as it alone explains about 50\% of the variation in this response. Clearly there is a synergy between the three factors in this model rather than a simple linear relationship, which reveals the complex nature of negotiation related to the choice of law following mergers.

Table 6

\begin{tabular}{|c|c|c|c|}
\hline $\begin{array}{l}\text { Probability } \\
\text { that Choice } \\
\text { of Law is } \\
\text { NY }\end{array}$ & $\begin{array}{l}\text { Choice } \\
\text { of } \\
\text { Forum } \\
\text { NY }\end{array}$ & $\begin{array}{l}\text { Acquirer } \\
\text { Atty. } \\
\text { Does Bus. } \\
\text { in NY }\end{array}$ & $\begin{array}{l}\text { Acquired } \\
\text { Private }\end{array}$ \\
\hline 0.96 & Yes & Yes & Yes \\
\hline 0.07 & No & Yes & Yes \\
\hline 0.84 & Yes & No & Yes \\
\hline 0.02 & No & No & Yes \\
\hline 0.80 & Yes & Yes & No \\
\hline 0.02 & No & Yes & No \\
\hline 0.50 & Yes & No & No \\
\hline 0.00 & No & No & No \\
\hline
\end{tabular}

iv) Logistic Regression Model for Choice of Forum Delaware

It is anticipated based on the logistic regression model for Choice of Law Delaware and the lack of independence between the Choice of Law Delaware and Choice of Forum Delaware that one of the most important factors, $x$, from Table 1 for this model would be Choice of Law Delaware. Other factors that influence this decision are revealed by the following logistic regression model, where it should be noted that all the factors are statistically significant at the $5 \%$ level of significance. 


\section{Parameter Estimates}

\begin{tabular}{|c|c|c|c|c|}
\hline Term & Estimate & Std Error & ChiSquare & Prob $>$ ChiSq \\
\hline Intercept & -4.80972189 & 0.7741824 & 38.60 & $<.0001 *$ \\
\hline $\begin{array}{l}\text { Acquirer Corp Office in } \\
\text { California? }\end{array}$ & -1.83628645 & 0.6177585 & 8.84 & $0.0030 *$ \\
\hline $\begin{array}{l}\text { Acquirer Attorney bus. } \\
\text { California? }\end{array}$ & +2.3312862 & 0.7067349 & 10.88 & $0.0010^{*}$ \\
\hline Acquirer Attorney bus. NY? & +1.5092787 & 0.5284111 & 8.16 & $0.0043 *$ \\
\hline Choice of Law New York? & -2.03376738 & 1.0053467 & 4.09 & $0.0431 *$ \\
\hline Choice of Law Delaware? & +5.8374106 & 0.78073 & 55.90 & $<.0001 *$ \\
\hline
\end{tabular}

From this model it follows that:

1. If the acquirer's corporate office is in California, the odds are less that the choice of forum will be Delaware as might be expected.

2. But if the acquirer's attorney does business in California, the odds are higher that the choice of forum will be Delaware.

3. If the acquirer's attorney does business in New York, the odds are still high that the choice of forum will be Delaware but not as high as when the acquirer's attorney does business in California.

4. If the choice of law is New York, the odds are less that the choice of forum is Delaware again because choice of law and choice of forum are not independent.

5. If the choice of law is Delaware, all other variables held constant, the odds are highest that the choice of forum is Delaware as was initially postulated.

Table 7 lists the actual odds or probabilities associated with all combinations of these five factors, which reveals the synergy among these five factors. The first nine rows are for Choice of Law Delaware. The second nine rows are for Choice of Law New York. The last set of nine rows is for Choice of Law other than Delaware or New York. 
Table 7

\begin{tabular}{|c|c|c|c|c|c|c|}
\hline $\begin{array}{l}\text { Probability } \\
\text { that Choice } \\
\text { of Forum DE }\end{array}$ & $\begin{array}{l}\text { Choice } \\
\text { of Law } \\
\text { DE? }\end{array}$ & $\begin{array}{l}\text { Choice of } \\
\text { Law NY? }\end{array}$ & $\begin{array}{l}\text { Acquirer } \\
\text { Corp. } \\
\text { Office } \\
\text { NY? } \\
\end{array}$ & $\begin{array}{l}\text { Acquirer } \\
\text { Corp. } \\
\text { Office CA? }\end{array}$ & $\begin{array}{l}\text { Acquirer } \\
\text { Atty. Does } \\
\text { Bus. In CA }\end{array}$ & $\begin{array}{l}\text { Acquirer } \\
\text { Atty. Does } \\
\text { Bus. In NY } \\
\end{array}$ \\
\hline 0.99 & Yes & No & Yes & No & No & Yes \\
\hline 0.97 & Yes & No & Yes & No & No & No \\
\hline 1.00 & Yes & No & Yes & No & Yes & No \\
\hline 0.64 & Yes & No & No & Yes & No & Yes \\
\hline 0.83 & Yes & No & No & Yes & Yes & No \\
\hline 0.32 & Yes & No & No & Yes & No & No \\
\hline 0.97 & Yes & No & No & No & Yes & No \\
\hline 0.91 & Yes & No & No & No & No & Yes \\
\hline 0.73 & Yes & No & No & No & No & No \\
\hline 0.02 & No & Yes & Yes & No & No & Yes \\
\hline 0.01 & No & Yes & Yes & No & No & No \\
\hline 0.05 & No & Yes & Yes & No & Yes & No \\
\hline 0.00 & No & Yes & No & Yes & No & Yes \\
\hline 0.00 & No & Yes & No & Yes & Yes & No \\
\hline 0.00 & No & Yes & No & Yes & No & No \\
\hline 0.00 & No & Yes & No & No & Yes & No \\
\hline 0.00 & No & Yes & No & No & No & Yes \\
\hline 0.00 & No & Yes & No & No & No & No \\
\hline 0.26 & No & No & Yes & No & No & Yes \\
\hline 0.08 & No & No & Yes & No & No & No \\
\hline 0.50 & No & No & Yes & No & Yes & No \\
\hline 0.00 & No & No & No & Yes & No & Yes \\
\hline 0.01 & No & No & No & Yes & Yes & No \\
\hline 0.00 & No & No & No & Yes & No & No \\
\hline 0.07 & No & No & No & No & Yes & No \\
\hline 0.03 & No & No & No & No & No & Yes \\
\hline 0.01 & No & No & No & No & No & No \\
\hline
\end{tabular}

v) Logistic Regression Model for Choice of Forum New York

Upon examining the factors listed in Table 1 as possible variables in a logistic regression model for Choice of Forum New York, only one factor was statistically significant, namely Choice of Law New York, which was expected based on the twofactor contingency table. But note that none of the other variables listed in Table 1 were statistically significant. And with this simplified model, $61 \%$ of the variation in Choice of Forum New York was explained as shown below (100*RSquare(U)).

RSquare (U)

Observations
0.6101

343 
The logistic model for Choice of Forum New York is as follows.

Parameter Estimates

Term

Intercept

Choice of Law New York?

\begin{tabular}{llll} 
Estimate & Std Error & ChiSquare & $\begin{array}{l}\text { Prob }>\text { ChiSq } \\
-3.46216439\end{array}$ \\
\hline 0.3385046 & 104.61 & $<.0001^{*}$ \\
+5.5903961 & 0.5817172 & 92.36 & $<.0001^{*}$
\end{tabular}

By transforming this logistic model to obtain $f(\underline{x})$, the probability of the Choice of Forum New York given Choice of Law New York is 89 percent.

vi) Logistic Regression Model for Acquirer Incorporates in Delaware

The logistic model shown below is for $T(Y)$, where $Y$ is "Acquirer Incorporates in Delaware." From this model one can predict the probability that the acquirer incorporates in a state other than Delaware as well as the complement probability. The terms shown in the model are all statistically significant and represent only those from the list in Table 1 that are statistically significant with p-values less than 0.05 .

$\underline{\text { Parameter Estimates }}$

$\underline{\text { Term }}$

Intercept

Choice of Law Delaware?

Choice of Law New York?

Acquirer Corp. Office in New

York?

Acquirer Corp Office in

California?

Stock? -1, Both? 0, Cash? 1

Acquirer Private?

\begin{tabular}{|c|c|c|c|}
\hline Estimate & $\underline{\text { Std Error }}$ & $\underline{\text { ChiSquare }}$ & $\underline{\text { Prob }>C h i S q}$ \\
\hline-1.16774078 & 0.2210379 & 27.91 & $<.0001 *$ \\
\hline+1.9171687 & 0.2759369 & 48.27 & $<.0001^{*}$ \\
\hline+1.1241658 & 0.3956299 & 8.07 & $0.0045^{*}$ \\
\hline+2.1683484 & 0.6616287 & 10.74 & $0.0010^{*}$ \\
\hline +1.1916121 & 0.334108 & 12.72 & $0.0004 *$ \\
\hline+0.4334862 & 0.1549729 & 7.82 & $0.0052 *$ \\
\hline-0.70675185 & 0.3122751 & 5.12 & $0.0236^{*}$ \\
\hline
\end{tabular}

As the following statistic indicates, only $21 \%$ of the variation in this response is explained by the terms in this model, that is, by the terms listed in Table 1 . Thus, other unknown factors contribute to whether or not the acquirer in a merger incorporates in Delaware.
RSquare (U)
0.2135
Observations
343

Table 8 shows the predicted probabilities of the acquirer incorporating in Delaware based on this model. The probabilities of the acquirer incorporating in Delaware for specific combinations of the significant factors in the model are all listed in this table. But a summary of some of these effects is as follows. 
First, if the choice of law is either Delaware or New York, the probability is higher that the acquirer will incorporate in Delaware than if the choice of law is some other state. Second, if the acquirer's corporate office is in either New York or California, the probability is higher that the acquirer will incorporate in Delaware than if the corporate office is in some other state. Third, if the financial arrangements of the merger are all cash, the probability is higher that the acquirer incorporates in Delaware than if the terms are stock and cash, and if the terms are stock only, the probability is even less that the acquirer will incorporate in Delaware. Finally, if the acquirer is private, the probability is less that the acquirer will incorporate in Delaware.

Table 8

\begin{tabular}{|c|c|c|c|c|c|c|}
\hline $\begin{array}{l}\text { Probability } \\
\text { that } \\
\text { Acquirer } \\
\text { Inc. in DE }\end{array}$ & $\begin{array}{l}\text { Choice of } \\
\text { Law DE? }\end{array}$ & $\begin{array}{l}\text { Choice of } \\
\text { Law NY? }\end{array}$ & $\begin{array}{l}\text { Acquirer } \\
\text { Corp. } \\
\text { Office NY? }\end{array}$ & $\begin{array}{l}\text { Acquirer } \\
\text { Corp. } \\
\text { Office } \\
\text { CA? }\end{array}$ & $\begin{array}{l}\text { Type } \\
\text { Purchase } \\
\end{array}$ & $\begin{array}{l}\text { Acquirer } \\
\text { Private? }\end{array}$ \\
\hline 0.82 & Yes & No & No & Yes & Stock & No \\
\hline 0.69 & Yes & No & No & Yes & Stock & Yes \\
\hline 0.87 & Yes & No & No & Yes & $\begin{array}{l}\text { Stock and } \\
\text { Cash }\end{array}$ & No \\
\hline 0.77 & Yes & No & No & Yes & $\begin{array}{ll}\text { Stock and } \\
\text { Cash }\end{array}$ & Yes \\
\hline 0.91 & Yes & No & No & Yes & Cash & No \\
\hline 0.84 & Yes & No & No & Yes & Cash & Yes \\
\hline 0.58 & Yes & No & No & No & Stock & No \\
\hline 0.40 & Yes & No & No & No & Stock & Yes \\
\hline 0.68 & Yes & No & No & No & $\begin{array}{l}\text { Stock and } \\
\text { Cash }\end{array}$ & No \\
\hline 0.51 & Yes & No & No & No & $\begin{array}{l}\text { Stock and } \\
\text { Cash }\end{array}$ & Yes \\
\hline 0.77 & Yes & No & No & No & Cash & No \\
\hline 0.62 & Yes & No & No & No & Cash & Yes \\
\hline 0.92 & Yes & No & Yes & No & Stock & No \\
\hline 0.86 & Yes & No & Yes & No & Stock & Yes \\
\hline 0.95 & Yes & No & Yes & No & $\begin{array}{l}\text { Stock and } \\
\text { Cash }\end{array}$ & No \\
\hline 0.90 & Yes & No & Yes & No & $\begin{array}{l}\text { Stock and } \\
\text { Cash }\end{array}$ & Yes \\
\hline 0.97 & Yes & No & Yes & No & Cash & No \\
\hline 0.93 & Yes & No & Yes & No & Cash & Yes \\
\hline 0.67 & No & Yes & No & Yes & Stock & No \\
\hline 0.50 & No & Yes & No & Yes & Stock & Yes \\
\hline 0.76 & No & Yes & No & Yes & $\begin{array}{l}\text { Stock and } \\
\text { Cash }\end{array}$ & No \\
\hline 0.61 & No & Yes & No & Yes & $\begin{array}{l}\text { Stock and } \\
\text { Cash }\end{array}$ & Yes \\
\hline 0.83 & No & Yes & No & Yes & Cash & No \\
\hline
\end{tabular}




\begin{tabular}{|c|c|c|c|c|c|c|}
\hline 0.71 & No & Yes & No & Yes & Cash & Yes \\
\hline 0.38 & No & Yes & No & No & Stock & No \\
\hline 0.23 & No & Yes & No & No & Stock & Yes \\
\hline 0.49 & No & Yes & No & No & $\begin{array}{l}\text { Stock and } \\
\text { Cash }\end{array}$ & No \\
\hline 0.32 & No & Yes & No & No & $\begin{array}{l}\text { Stock and } \\
\text { Cash }\end{array}$ & Yes \\
\hline 0.60 & No & Yes & No & No & Cash & No \\
\hline 0.42 & No & Yes & No & No & Cash & Yes \\
\hline 0.84 & No & Yes & Yes & No & Stock & No \\
\hline 0.73 & No & Yes & Yes & No & Stock & Yes \\
\hline 0.89 & No & Yes & Yes & No & $\begin{array}{l}\text { Stock and } \\
\text { Cash }\end{array}$ & No \\
\hline 0.80 & No & Yes & Yes & No & $\begin{array}{l}\text { Stock and } \\
\text { Cash }\end{array}$ & Yes \\
\hline 0.93 & No & Yes & Yes & No & Cash & No \\
\hline 0.86 & No & Yes & Yes & No & Cash & Yes \\
\hline 0.38 & No & Yes & No & No & Stock & No \\
\hline 0.40 & No & No & No & Yes & Stock & No \\
\hline 0.25 & No & No & No & Yes & Stock & Yes \\
\hline 0.51 & No & No & No & Yes & $\begin{array}{l}\text { Stock and } \\
\text { Cash }\end{array}$ & No \\
\hline 0.34 & No & No & No & Yes & $\begin{array}{l}\text { Stock and } \\
\text { Cash }\end{array}$ & Yes \\
\hline 0.61 & No & No & No & Yes & Cash & No \\
\hline 0.44 & No & No & No & Yes & Cash & Yes \\
\hline 0.09 & No & No & No & No & Stock & Yes \\
\hline 0.24 & No & No & No & No & $\begin{array}{l}\text { Stock and } \\
\text { Cash }\end{array}$ & No \\
\hline 0.13 & No & No & No & No & $\begin{array}{l}\text { Stock and } \\
\text { Cash }\end{array}$ & Yes \\
\hline 0.32 & No & No & No & No & Cash & No \\
\hline 0.19 & No & No & No & No & Cash & Yes \\
\hline 0.64 & No & No & Yes & No & Stock & No \\
\hline 0.47 & No & No & Yes & No & Stock & Yes \\
\hline 0.73 & No & No & Yes & No & $\begin{array}{l}\text { Stock and } \\
\text { Cash }\end{array}$ & No \\
\hline 0.57 & No & No & Yes & No & $\begin{array}{l}\text { Stock and } \\
\text { Cash }\end{array}$ & Yes \\
\hline 0.81 & No & No & Yes & No & Cash & No \\
\hline 0.67 & No & No & Yes & No & Cash & Yes \\
\hline
\end{tabular}

\section{EMPIRICAL RESEARCH: THE IMPLICATIONS FOR SCHOLARLY RESEARCH WITH DATA}

This section raises broader questions about empirical research based on readily available historical data, rather than data from statistically designed and controlled 
experiments. These questions may be relevant to deciding how such research is conducted, and may shed light on the limits of drawing conclusions based solely on quantitative data in the absence of any theory or hypotheses to test. Are there questions that raw data cannot resolve and why would this be so? Empirical research raises questions about when its results can or should be used to draw normative implication and about what approach the law should take, given a certain empirical "reality." Is there a structure that needs to exist before those normative implications can be drawn? Under what circumstances does data-driven empirical research suggest the need for further qualitative research without which we cannot make normative recommendations?

Analysis of merger data raises two fundamental questions. First, to avoid identification of a merely transient event, empiricists need to confront how much data they need to study before drawing conclusions. It may be difficult to identify a phenomenon such as a flight in the choice of law when that choice can quickly change. The second fundamental question addresses whether raw numbers by themselves can illuminate an issue based on a choice by parties, or whether empiricists need to gather qualitative data on why the choice was made and by whom in order to draw meaningful conclusions.

Before critiquing empirical work, the benefits should be noted. Empirical research in a field such as law can illuminate how parties actually behave. In one of the early empirical studies in contract law, Professor Stewart Macaulay studied Wisconsin businessmen and lawyers. Through in depth interviews Macaulay found that businessmen were likely to ignore the legal niceties of contract law and to rely instead on informal mechanisms to resolve disputes. ${ }^{46}$ That study and its insights inspired an entire generation of scholars to study informal mechanisms between contracting parties. ${ }^{47}$ It prompted examinations of entire social networks that provided source of order without legal intervention. It caused legal scholars to study experimental data on the interaction between informal and formal mechanisms ${ }^{48}$ and the crowding out phenomenon ${ }^{49}$ and to reexamine the role of law in transactions. Empirical research can thus cause scholars to rethink entire fields of law, such as contract law, and to question previously unquestioned assumptions, such as the centrality of law in parties' decision-making. ${ }^{50}$

Empirical research can be used to test legal theories of how parties would be likely to behave in response to legal rules. Macaulay looked at whether the law of contract influenced the way businessmen behaved in their transactions and how they dealt with disputes and wrote their contracts. In the corporate context, many scholars have studied the dominance of Delaware incorporations and proposed theories to explain the

\footnotetext{
${ }^{46}$ Stewart Macaulay, Non-Contractual Relations in Business: A Preliminary Study, 28 AM. Soc. Rev. 1 (1963).

${ }^{47}$ Douglass North, Institutional Change And Economic Performance (2004); See Robert C. ElLickson, ORder Without Law, How Neighbors SeTtle DisPutes (1991); See also Lisa Bernstein, Opting Out of the Legal System: Extralegal Contractual Relations in the Diamond Industry, 21 J. LEGAL STUD. 115 (1992).

${ }^{48}$ See Avner Greif, InSTITUTIONS AND THE PATH TO THE MODERN ECONOMY LESSONS FROM MEDIEVAL TRADE 293 (2006) (studying informal dispute mechanisms of the Maghribi traders).

${ }^{49}$ Kraus \& Scott, supra note 12, at 1058 (discussing crowding out).

${ }^{50} \mathrm{See}$ OLIVER E. WilLIAMSON, ECONOMIC INSTITUTIONS OF CAPITALISM (1985).
} 
preference. ${ }^{51}$ In the context studied here, involving the choice of law in the merger context, scholars examined whether empirical data on the choice of law mirrored Delaware's dominance in the chartering decision and sought to determine whether a flight to New York from Delaware choice of law existed and to identify the factors that accounted for the parties' choice of law. They examined whether parties incorporated in Delaware reacted to Delaware law by fleeing from it and choosing another state's law. They were looking at how the parties reacted to the law of a jurisdiction either by embracing it or by rejecting it. Empirical research, thus, often helps resolve important questions that would otherwise remain unanswered or subject to speculation: i.e., is there a flight to New York from Delaware as the choice of law in merger agreements?

\section{A. Determining How Much Data Is Necessary to Draw Conclusions}

To determine how to resolve questions through data collection, an empirical researcher must confront how much data needs to be studied in order to gain an accurate picture of reality to illuminate an issue and to be able to predict future behavior or events. All three papers mentioned above, the Eisenberg and Miller study, the Cain and Davidoff study, and this study, sought to resolve whether there was a flight to New York from Delaware for the choice of law in merger agreements.

The authors selected different time periods and used different data sets. To test their hypothesis of a flight, Professors Eisenberg and Miller studied a seven-month period in 2002. We studied a six-month period in 2011 (January 1, 2011-June 30, 2011). The Cain and Davidoff study broke up that span of time into three separate ones ${ }^{52}$ to take account of some significant real world events. Interestingly enough, Eisenberg and Miller used their data to show a flight based on the fact that Delaware incorporated companies were less likely to select a Delaware choice of law than a New York incorporated company was to select New York for the choice of law. ${ }^{53}$ They based their concept of a flight on the idea that Delaware incorporated companies choosing not to select a Delaware choice of law were therefore presumably fleeing Delaware. ${ }^{54}$ Fewer companies selected Delaware law that were incorporated in Delaware. The reverse was true for New York incorporated companies; in that case, even though a very small number of companies were incorporated in New York, a disproportionately large numbers of companies opted

${ }^{51}$ See, e.g., William Cary, Federalism and Corporate Law: Reflections Upon Delaware, 83 YALE L. J. 663 (1974); See also, Daniel Fischel, The 'Race to the Bottom' Revisited: Reflections on Recent Developments in Delaware's Corporation Law, 76 Nw. U. L. REV. 913 (1987).

${ }^{52}$ See infra text accompanying notes 58-66.

${ }^{53}$ Eisenberg \& Miller, supra note 7, at 1989.

${ }^{54}$ As Cain and Davidoff explain, the Eisenberg and Miller study "found that Delaware was chosen as the governing law 32.0 percent...of the time. The authors conclude that this represents a flight from Delaware since 40.8 percent of targets and 45.9 percent of acquirers were incorporated in Delaware." Cain \& Davidoff, supra note 4, at 95. A different theory of flight could have addressed whether a change in the frequency with which Delaware law was chosen over different time periods would have precipitated a different non-static data collection. 
for a New York choice of law provision. ${ }^{55}$ Based on that discrepancy, Professors Eisenberg and Miller studied a series of factors such as attorney locale and the place of business for the acquiring and acquired companies, and then used regression analysis to determine if, after adjusting for these factors, there is a flight to New York away from Delaware. Ultimately, their "results confirm the flight from Delaware" 56 to New York.

We have already argued in Part I that there are difficulties with using the relative flight result based on showing fewer choices of law than incorporations for several reasons. First, the new data does not support the flight thesis in the later period we studied. In the first six months of 2011, the actual percentage of incorporations in Delaware that choose Delaware law, 65\%, is not significantly different from the percentage of incorporations in states other than Delaware that select the same state other than Delaware for their choice of law, 70\%, with the conservative assumption about the other states of incorporation and choice of law. The Eisenberg and Miller conjecture based on 2002 merger history is not true based on 2011 merger history. This highlights the danger that studying empirical data may identify only a transient phenomenon making it difficult to draw significant conclusions about future behavior without tracking data sets over time to determine whether the identified pattern holds true. Without that assurance, it is premature to reach normative conclusions founded on the potentially transient phenomena. Second, even if the data were accurate for a certain time period, the ability to draw meaningful conclusions may depend on other factors that are not captured by the data itself. For example, it may be hard to draw conclusions if actual data suggests that the lawyers drafting the agreements said that they would be happy with either Delaware or New York. ${ }^{57}$ The concern about the drafting lawyers being open to and relatively indifferent to New York and Delaware suggests that there are significant limits to drawing conclusions about choices without a meaningful engagement with the underlying context and reasons behind those choices.

Assuming that the choice matters and the parties make deliberate choices based on perceived stark differences, scholars can solve the transient phenomenon by exploring the issue over an extended period of time. Professors Cain and Davidoff have explored the question of whether a flight to New York existed in a different way by comparing the results in three data sets. They studied a four-year period from 2004-2008; however, instead of using one period, they looked at three different periods, two of which were tied to significant events, the Consolidated Edison v. Northeast Utilities case ${ }^{58}$ and the financial downturn. They therefore approached the empirical data differently to assess the same question: whether a flight to New York existed. They found a weak trend to New

\footnotetext{
${ }^{55}$ See Eisenberg \& Miller, supra note 7, at Table 3A 1989. As Cain and Davidoff explain, "through double sortings of variable and logit models, the authors document a general trend toward non-Delaware law...in early 2002." Cain \& Davidoff, supra note 34, at 99-100.

${ }^{56}$ Eisenberg \& Miller, supra note 7, at 1974.

${ }^{57}$ See Kostritsky, supra note 25, at 229, reporting that $92 \%$ of lawyers involved in the same set of merger agreements studied in this paper are very comfortable or comfortable with Delaware law and $87 \%$ of such lawyers are very comfortable or comfortable with New York law. Thus, data suggests that lawyers are comfortable with the law of either jurisdiction.

${ }^{58}$ See Consol. Edison v. Ne. Utils., 426 F.3d 524 (2d Cir. 2005).
} 
York in the first period ${ }^{59}$ but a subsequent trend to Delaware after Consolidated Edison ${ }^{60}$ which then accelerated after the financial recession. ${ }^{61}$

What they found was that it was a complex picture and there was no unified flow. Instead, while early on they found a "negative flow away from Delaware,"62 later on the flow reversed so that by the financial crisis in 2008, there was a "strong flow toward Delaware." ${ }^{\prime 63}$

After tying the increase in flow toward Delaware to Consolidated Edison and the 2008 financial crisis, both external events, Cain and Davidoff then developed explanations that made sense of both the choice of law and the other events. Using empirical data showing a variation in the flow, they developed a theory to help explain why the financial crisis would have precipitated a flow given "that legal actors are responsive to changes in both law and adjudicative certainty." ${ }^{\prime 4}$ The greater expertise of Delaware judges was not enough to compel companies to choose Delaware all the time with the same frequency for all time periods, yet they did so at an increasing rate after the financial recession and an adverse court decision. This led Professors Cain and Davidoff to conclude that "Delaware's edge in the market for corporate law may be dependent on its ability to produce law that is attractive to merging corporations." ${ }^{65}$ The picture of choice of law that emerges is a complex one in which Delaware is portrayed as having "competitive stature," 66 in the sense that variations in the law play a role in influencing the choice of law. ${ }^{67}$ This explanation seems consistent with lawyers who remark on the current salient differences between New York and Delaware law and demonstrate an interest in current law by commenting on the latest practitioner manuals documenting the differences. ${ }^{68}$ Professors Cain and Davidoff built a theory of a reverse flight or trend by comparing the frequency with which Delaware law was chosen over three different time periods. Thus, there is a change in the disparity of choice of law in a time series when the data are viewed as a time series.

Our study uses a complete count ${ }^{69}$ based on the EDGAR SEC database data in one time period, January 1, 2011 to June 30, 2011. ${ }^{70}$ It uses the Eisenberg and Miller data

${ }^{59}$ Cain \& Davidoff, supra note 34 , at 94.

${ }^{60} \mathrm{Id}$. at 95 .

${ }^{61} I d$. at 94 .

${ }^{62} I d$. at 95.

${ }^{63} I d$.

${ }^{64} I d$.

${ }^{65} \mathrm{Id}$. This insight is consistent with one that I gained in a study surveying M\&A lawyers who seem sensitive to changes in the laws that affect merger agreements; see Kostritsky, supra note 25. ${ }^{66}$ Cain \& Davidoff, supra note 34, at 94.

${ }^{67}$ In a separate paper, Juliet Kostritsky surveyed lawyers and found that the choice of law is made primarily by lawyers, not clients. See supra note 25 , at 221-22.

${ }^{68} I d$.

${ }^{69}$ We did not exclude any mergers because they lacked certain characteristics and so we have a complete count study.

${ }^{70}$ In an earlier version of the paper we also compared the frequency with which Delaware law is specified and find an increase in the frequency with which agreements are specifying Delaware as the choice of law when compared to the earlier Eisenberg and Miller study. 
as a benchmark for comparison. ${ }^{71}$ Our study confirms the Cain and Davidoff study and negates the conjecture of a trend toward New York choice of law and away from Delaware choice of law.

These different studies raise three theoretical and conceptual questions for legal scholarship. First, how much reality do we need to observe in order to get an accurate picture that can provide a foundation for drawing both positive and normative conclusions about future behavior? Because lawyers can easily choose to change the choice of law with every agreement drafted, ${ }^{72}$ studying a limited time period may limit the ability to detect changes in choice of law over time that respond to changes in the relevant law. The Cain and Davidoff study demonstrated that the choice of law appears sensitive to changes in the law and society, making it necessary to measure the choice of law at different points in time.

Second, the construction of time periods against which to conduct a comparative study to take account of significant life events raises the question of whether an explanatory theory using data can be built using the disparity in the choice of law in a time series to comprise a trend associated with the triggering events, without doing further empirical research on the choices made by the lawyers actually drafting the agreements. A further study by Professors Cain and Davidoff or others could follow up to determine what effect the financial recession and the failed Consolidated Edison merger ${ }^{73}$ actually played in the thinking of the lawyers making the choice of law decisions and whether other factors played a role as well. A separate study by Professor Juliet Kostritsky surveyed the 812 lawyers drafting the merger agreements in the 2011 data set and examined the reasoning underlying the choice of law.

Third, the empirical evidence of Eisenberg and Miller finding a flight to New York law, and the later study of Cain and Davidoff finding a choice of law decision changing over time and responding to external events in society and the law, ${ }^{74}$ implicates the question of why we care about empirical evidence and how the evidence will enhance our understanding of how and why parties opt for a particular law to govern their merger agreement. ${ }^{75}$ The Eisenberg and Miller study identified factors that might be associated with and influential on the choice of law and found, after using multiple regression methods that account for those factors, a flight to New York. Cain and Davidoff

\footnotetext{
71 Our study does the same using the Eisenberg \& Miller study as a baseline for comparison.

72 Cain and Davidoff make the point that every agreement offers a new chance to choose a choice of law. Cain \& Davidoff, supra note 34, at 93.

732001 was the year of the failed merger but 2005 was the date of the first court decision.

74 "Nonetheless while a firm's state of incorporation carries significant weight, the choice of law in merger agreements can be affected by court decisions and statutes." Cain \& Davidoff, supra note 34, at 97.

75 See Edward Rubin, Empiricism's Crucial Question and the Transformation of the Legal System, in REVISITING THE CONTRACTS SCHOLARSHIP OF STEWART MACAULAY ON THE EMPIRICAL AND THE LYRICAL 77 (2013) (noting the "crucial insight" of Professor Macaulay and the empiricists that we need to find out whether the laws we have devised are "produc[ing] some effect in the real world.").
} 
"document a new flight over time to Delaware." factors are associated with the parties' choice of law, help to pinpoint the time period associated with a shift in the choice of law, and help to resolve whether there is a flight to Delaware away from New York. Perhaps we can surmise that the choice of law provisions is working to enhance party choice, and the very existence of changes in the choice of law indicates that parties are taking advantage of that freedom. If party choice is a primary goal of the legal system, then the data seem to confirm the achievement of one goal in allowing parties to choose the law to govern their agreements.

\section{B. Studying a Flight from Delaware: A Complex Subject for Analysis}

Empirical studies may need to collect data over time in order to gain an accurate picture designed to study the flight from Delaware law. But in focusing on a subject for empirical data collection and then building a theory that Delaware companies are fleeing Delaware and thereby Delaware law, the identification of a subject that is appropriate for empirical research is critical. Such studies also raise interesting issues that may conceal underlying problems, which might make the data collected difficult to interpret or even misleading. For example, studying a supposed flight may be problematic for a number of reasons that are not discussed in prior studies of the issue.

First, it might be entirely unsurprising that there is a net outflow from Delaware but it would be strange to necessarily jump to the conclusion that there is an aversion to Delaware law, which a flight thesis implies. There might be all kinds of non-law reasons to choose some other jurisdiction for any particular agreement like a merger agreement. The Eisenberg and Miller study seems to assume that there are substantive legal reasons underlying the flight to New York for the choice of law; otherwise, why describe it as a flight? If no aversion to Delaware law exists, then there is no reason to describe the choice of New York law as a flight from Delaware.

Second, there can be an outflow from Delaware in the first place because there is such a tremendous inflow into Delaware and because of the perceived benefits of their legal system. Conversely, there can hardly help but be an inflow to New York given the dearth of New York incorporations. To claim a departure from a baseline that is enormously skewed towards Delaware law constitutes a flight from Delaware law seems misguided. As one colleague commented, it has a "Nobody goes there anymore, it's too crowded" connotation. ${ }^{77}$

Third, it is unclear whether the raw numbers on choice of law and forum tell us anything about the desirability of either jurisdiction's law. It is difficult to draw any meaningful conclusions without knowing why there was a flight. To prove a flight, you would need to demonstrate that the decision to leave a jurisdiction was knowing, volitional, and deliberate with respect to the content of the law of a jurisdiction. To reach meaningful conclusions about a choice, it would be important to interview the lawyers

\footnotetext{
${ }^{76}$ Cain \& Davidoff, supra note 34, at 95. "Ultimately we found a weak trend toward Delaware and away from New York after the Consolidated Edison decision and a strong flow toward Delaware in the financial crisis." Id.

${ }^{77}$ Charles Korsmo interview.
} 
who think of underlying the choice of law in a merger agreement. That data is now available. ${ }^{78}$

\section{Determining Whether Raw Numbers Can Illuminate Party Choice}

Before attaching significance to data and before finding a flight, one must first show that there has been a volitional movement, i.e., not a change in pattern of law selection that is coincidental or happenstance, but an intentional decision (any intent, but more than mere chance) to favor one state over the other. One must also rule out decisions that are made with a gun to one's head or choices that are under the influence of a random selection machine. So, one or two sets of numbers by themselves do not prove a flight. To prove a flight, you need to find one or more reasons that caused the flight, and that they were made intentionally.

One intentional form of decision is called habit or custom. That is, one might choose a state law because it is customary to do so, or because one has made a habit of doing so. Habits and customs grow up over time, but start as volitional decisions. Someone decided to incorporate new companies in Delaware, and over time the decision where to incorporate became a habit. So now many lawyers incorporate everything in Delaware without thinking about it. There may have been good reasons to do so ab initio, but habit and herd instinct are now the drivers, not careful thought.

In the 2002 study when the predominant choice of incorporation was Delaware followed by New York, Professors Eisenberg and Miller found a flight based on these numbers: 181 incorporations were in Delaware while there were only 135 choice of law clauses selecting Delaware. There is a "flight" in the sense that Delaware corporations picked Delaware law to govern in only $135 / 181$ corporations. The reverse was true for New York -in which 5 companies were incorporated in New York, and 63 corporations selected New York law. In the first six months of 2011, there were 42 mergers in which the choice of law was New York. Of these mergers, 25 or $59.52 \%$ were incorporated in Delaware and 17 or $40.48 \%$ were incorporated in states other than Delaware. Testing the alternative hypothesis "flight from Delaware" incorporation for choice of law New York versus the null hypothesis of "no flight from Delaware" incorporation for choice of law New York reveals there is insufficient information to reject this null hypothesis in favor of the alternative (P-value 21.7\%). This result is contrary to the claims by Eisenberg and Miller. ${ }^{79}$

To draw conclusions on the significance and meaning of a choice of law, in empirical research such as ours, or other prior studies, we need to examine the choice of law decisions closely to determine that the choice of law decision to determine that that the choice of law was volitional and not mere happenstance. Since the choice of law can be chosen each time with each new merger agreement, there is reason to believe that it was more than mere chance that resulted in the choice of law. Moreover, our regression analysis of the data clearly demonstrated the strong dependence among different factors affecting the choice of law.

\footnotetext{
78 See Kostritsky, supra note 25.

${ }^{79}$ Eisenberg \& Miller, supra note 7.
} 
But even if the choice is not happenstance, and is not a coincidence, there are reasons to question how much volition and intent one can attach to the choice of law data for several reasons and those limitations may narrow the implications one can draw from the data on "choice." If the choice is the result of habit or perhaps an unreflective copying of a prior language in a prior agreement by a lawyer, then it may be hard to argue that there is anything more at work than a bystander herd effect. Without more and without different forms of evidence, we cannot know what really drove the decision making it harder to draw meaningful conclusions from the choice.

Moreover, when a court looks at a party's choice, and talks about their intent or agreement to something such as a choice of law, the court subsumes into what it calls "the party's intent" all of the conscious and unconscious decisions that were actually made by party's agents and advisors, without those persons necessarily - and in fact usually notinforming the principal. Decisions made by the agent/advisor without the knowledge or understanding of the decision or its implications are thus imputed to the party.

In addition, a corporate lawyer may be ignorant of many state's laws, and thus, even if the merger agreement selects a particular state law to govern, it may not reflect a deliberative choice. Choice of law is an area where this would be almost universally so, since few laymen - and not all that many lawyers - have any concept of the real differences between state laws. Choice of law is a material element of very few law school courses. This ignorance is then compounded by bar exams, which primarily test on model codes and universal concepts rather than specific state laws. Many junior lawyers will have never considered choice of law issues when they go to draft an agreement, and many will copy (and potentially misuse) the precedents on which they rely.

Another issue complicating the choice of law issue is that the lawyer is acting on behalf of the client/commercial firm who is the principal. These issues of choice arising in the context of principal and agent raise the difficult issue of determining the extent to which the choice ${ }^{80}$ reflects the principal's choice at all, making it difficult to attribute meaning to the object of the principal's choice. At the same time, there is a cost/benefit issue here that makes this choice of law decision a non-issue in the vast majority of cases. Very few contracts are ultimately the subject of any dispute, and it is even rarer for the choice of law to be significant in a dispute. Applied to contracts generally, choice of law has a very slight impact. There are exceptions, such as the case of non-compete covenants, where the provisions may be void in one state and enforceable in another; another is in the case of security documents in real estate transactions involving a state like California, with its one action rule that would absolutely frustrate lenders who don't know about it. Lawyers who work in those fields would generally be expected to know about that problem. But where the risk of litigation is slight, the time spent worrying about choice of law is minimized for efficiency sake. After all, someone has to pay for the legal analysis, and few clients will pay for a thorough review of "boilerplate" terms, absent some significant reason to do so. There will be precious few times when a client will be able to say that "oh yes, I would have killed the deal had I known the potential impact of the difference in state law."

${ }^{80}$ See Robert C. Clark, AgENCY COSTS VERSUS FiduCIARY DUTIES, IN PRINCIPALS AND AGENTS: The Structure of Business 55 (John W. Pratt \& Richard J. Zeckhauser, eds., 1990). 
For example, if one looks at the 2002 study, because only 135 corporations chose Delaware law out of 181 Delaware corporations, we might have to figure out what was going on with the 46 who opted out of Delaware law, perhaps to New York law, before we could draw meaningful conclusions. If many of those 46 did not consider the choice at all, or did not care because it was not one of the main business points, or the lawyer chose and did not inform the principal, then even if the party did not "choose" Delaware, we cannot assume they knowingly opted out of Delaware. Further, for any of the 46 who chose not to have Delaware law govern a Delaware chartered corporation in a merger agreement, and who considered the choice, there might be many reasons contributing to the decision. Before one could draw meaningful conclusions from a flight to New York or to Delaware, we would need to analyze those reasons.

Moreover, since there are budget constraints on parties, if the 46 who opted out of Delaware thought that the choice of law was unimportant, there may be no significance to the opt out. Why call it a flight at all? Moreover, if the lawyer thought that choice of law needed to be in every agreement, but that it did not matter much what law was specified, ${ }^{81}$ then it would be hard to argue that there was a flight in a meaningful sense or that the parties had an aversion to Delaware law. Thus, even if there were a greater frequency with "Delaware corporations tend to choose Delaware law less than other corporations choose the law of their state of incorporation" (a result we did not find validated in our 2011 study), it may be hard to draw conclusions if actual data suggests that the lawyers drafting the agreements said that they would be happy with either Delaware or New York. If the drafting lawyers were open to and relatively indifferent to New York and Delaware, there would be significant limits on drawing conclusions on choices without a better understanding of the underlying context and reasons underlying the choice.

Finally, these empirical studies not only raise possible caveats on when we can establish a knowing and deliberate flight, and what conclusions to draw from a flight, they also seem implicitly to reject the idea that there can be one "overarching" explanation for a choice of law, such as the superior expertise of the Delaware judiciary or a unitary preference for formalism, ${ }^{82}$ unless further empirical studies are conducted to compare the influence of that factor with other determinants. It is possible to imagine that an empirical study could be conducted that isolated formalism as one of the factors contributing to a choice of law decision, and compared its effect on the choice of law with other factors that actually influenced the decision and the lawyer making the choice. The complexity of the influences on choice of law suggests that it could be difficult to find that a choice of law, made at a particular point in time, can be explained by a unitary theory, such as a preference for formalism. Caution in explaining the choice of law or any other variable seems to be the most important lesson from these empirical studies. However, that caution should not deter further studies on formalism as an influence on the choice of law decision by lawyers and clients; it may be an important subject for further study, but such further studies should be careful to consider qualitative research to provide context.

\footnotetext{
81 See Kostritsky, supra note 25.

82 The new formalists relied on the initial findings of a flight to New York to conclude that parties prefer New York because of its formal nature and that courts should follow their lead. See Kraus \& Scott, supra note 12, at 1061-62.
} 
Our own empirical study on the flight issue convinced us that before we could draw implications from studying a flight pattern, we needed more information from those actually making the choice of law decisions. ${ }^{83}$ Thus, it may be that in seeking to confirm or disaffirm initial conclusions on the factors influencing the choice of law, work should first be conducted to ascertain the influence of all those factors on the lawyer or on lawyers and clients.

\section{CONCLUSION}

In this study, we observed and confirmed the strong correlation between the choice of law and the factors suggested by Professor Miller and Eisenberg: business locale, attorney locale, and state of incorporation. Without dispute, Delaware's dominance as the state of incorporation heavily influences subsequent decisions when it comes to the choice of law to govern corporate mergers. As elucidated in Table 3, Delaware law governed more than fifty percent of merger contracts. ${ }^{84}$ This is unsurprising, since Delaware was the state of incorporation for more than half of the acquirers we studied ${ }^{85}$ However, the significance of this study is to examine the outflow from Delaware as suggested by Professors Eisenberg and Miller. To that end, while we are able to conclude that New York is indeed the second most frequently selected state behind Delaware (by comparing data gathered in 2002 and 2011), we find that the actual percentage of incorporations in Delaware that choose Delaware law is not significantly different from the percentage of corporations in states other than Delaware that select the same state other than Delaware for their choice of law. This negates the Eisenberg and Miller conjecture of a flight from Delaware. We nonetheless confirmed that, for New York, choice of forum influences corporate decisions in the choice of law for New York.

Our results, along with Professor Miller and Eisenberg's results, generate one crucial question for further research. While scholars continue to debate how each factor influences the choice of law, the essential question that is closest to the interest of the bar remains simple: what influences practitioners to choose a certain state law over another to govern merger deals? Without further empirical evidence on the potential drivers behind the choice from direct evidence, we may not be able to identify the statistically significant drivers behind those choices. Statistical analysis provided insight into how a variety of factors correlated with the choice of law and choice of forum-how merger attorneys perceive these factors, whether and how these factors indeed influence practitioners when deciding the choice of law, or whether other rationales drive the ultimate choice of law decision. Information that is now available in a forthcoming study can help further interpret the meaning of the data and the choices.

The prior empirical studies of the flight issue raise important questions about the methodology of empirical research and the restrictions imposed when drawing normative

\footnotetext{
83 See Kostritsky, supra note 25.

84 See supra Table 3.

85178 of 334 acquirers were incorporated in Delaware, which accounted for $53.29 \%$.
} 
implications on choice of law from a limited data set without further data collection from the lawyers making the choices.

Finally, the data did not bear out the Eisenberg and Miller hypothesis, and data alone cannot provide useful insight into whether there is a flight from Delaware and, if there is one, why it is occurring. 